\title{
The Difference between Sheared and Granular Peridotites
}

Hatton, C.J.

Anglo American Research Laboratories (Pty) Ltd., P.O. Box 106, Crown Mines 2025, Johannesburg.

Sheared peridotites are often considered to be derived by metasomatism of granular peridotites (Ehrenburg, 1979; Gurney and Harte, 1980; Smith et al., 1993). However the differences between these two suites are too profound for this hypothesis to be tenable.

Sheared peridotites have rare earth and high field strength element concentrations which are close to chondritic (Shimizu, 1975; BVSP, 1981; Shimizu and Allègre, 1978). Depletion of sheared peridotites is demonstrated by Re-Os ratios (Walker et al., 1989), and this depletion may also be responsible for the non-chondritic $\mathrm{CaO} / \mathrm{Al}_{2} \mathrm{O}_{3}$ ratio of sheared peridotites. Addition of a majorite garnet component, as included in Monastery diamonds, to sheared peridotite produces chondritic $\mathrm{CaO} / \mathrm{Al}_{2} \mathrm{O}_{3}$ ratios, but silica contents are below the $48-50 \%$ range of chondritic mantle (Taylor and McLennan, 1985; Anderson, 1983) (Table 1). This suggests that sheared peridotites formed from mantle which first lost silica to the core, then underwent majorite extraction. Majorite, rather than basalt, is extracted becauses partial melting extracts low-temperature melt from the basalt during subduction, and only the refractory majorite or eclogite residuum reaches the lower mantle.

\begin{tabular}{|c|c|c|c|c|}
\hline & $\begin{array}{l}\text { Average } \\
\text { mantle }\end{array}$ & $\begin{array}{l}\text { Majorite } \\
\text { extract }\end{array}$ & $\begin{array}{l}\text { Primitive } \\
\text { Mantle } \\
\text { Calculated }\end{array}$ & $\begin{array}{l}\text { Primitive } \\
\text { Mantle } \\
\text { McD\&S }\end{array}$ \\
\hline $\mathrm{SiO}_{2}$ & 44.30 & 42.08 & $\quad 44.01$ & 45.00 \\
\hline $\mathrm{TiO}_{2}$ & 0.09 & 0.99 & 0.21 & 0.20 \\
\hline $\mathrm{Al}_{2} \mathrm{O}_{3}$ & 2.36 & 17.74 & 4.36 & 4.45 \\
\hline $\mathrm{Cr}_{2} \mathrm{O}_{3}$ & 0.43 & 0.04 & 0.38 & 0.38 \\
\hline $\mathrm{FeO}$ & 8.31 & 15.09 & 9.19 & 8.05 \\
\hline $\mathrm{MnO}$ & 0.13 & 0.29 & 0.15 & 0.14 \\
\hline $\mathrm{MgO}$ & 41.64 & 11.12 & 37.67 & 37.80 \\
\hline $\mathrm{CaO}$ & 2.20 & 12.03 & 3.48 & 3.55 \\
\hline $\mathrm{Na}_{2} \mathrm{O}$ & 0.23 & 0.71 & 0.29 & 0.36 \\
\hline $\mathrm{K} 2 \mathrm{O}$ & 0.04 & & 0.03 & 0.03 \\
\hline $\mathrm{NiO}$ & 0.27 & & 0.23 & 0.25 \\
\hline Total & 100.00 & 100.10 & 100.01 & 100.21 \\
\hline $\mathrm{CaO} / \mathrm{Al}_{2} \mathrm{O}_{3}$ & 0.93 & 0.68 & 0.80 & 0.80 \\
\hline $\mathrm{SiO}_{2} / \mathrm{MgO}$ & 1.06 & 3.78 & 1.17 & 1.19 \\
\hline
\end{tabular}

Table 1. Composition of Primitive Mantle calculated by addition of 0.87 Average Mantle (Herzberg, 1993) and 0.13 Monastery Majorite sub-population (Moore et al., 1991; Hatton, 1993). Primitive Mantle of McDonough and Sun (1995) is presented for comparison.

Granular peridotites have heavy rare earth and titanium contents which are much lower than chondritic (Shimizu, 1975; BVSP, 1981; Shimizu and Allègre, 1978). 
Only very severe depletion, in multiple depletion events which culminated in komatiite extraction, can account for this. A two-stage melting event, involving extraction of iron-rich basalt, followed by komatiite extraction is shown in Table 2 . The source rock has high silica, and could have originated from chondritic mantle, possibly added to the earth by impact after earlier extraction of $\mathrm{Si}$ to the core (Herzberg, 1993).

\begin{tabular}{|c|c|c|c|c|c|c|c|}
\hline & $\begin{array}{l}\text { Kaapvaal } \\
\text { Peridotite } \\
\text { PHN4265 }\end{array}$ & $\begin{array}{l}\text { Barberton } \\
\text { komatiite } \\
49 \mathrm{~J}\end{array}$ & $\begin{array}{l}49 \mathrm{~J} \\
\text { Source } \\
\text { Calculated }\end{array}$ & $\begin{array}{l}\text { Iron-rich } \\
\text { basalt } \\
\mathrm{ACH} 7\end{array}$ & $\begin{array}{l}\text { ACH7 } \\
\text { Source } \\
\text { Calculated }\end{array}$ & $\begin{array}{l}\text { Primitive } \\
\text { Mantle } \\
\mathrm{ACH} 7 \\
\text { Source-Si }\end{array}$ & $\begin{array}{l}\text { Primitive } \\
\text { Mantle } \\
\text { McD\&S }\end{array}$ \\
\hline $\mathrm{SiO}_{2}$ & 48.13 & 46.01 & 47.80 & 52.66 & 48.80 & 45.00 & 45 \\
\hline $\mathrm{TiO}_{2}$ & 0.01 & 0.2 & 0.04 & 0.64 & 0.16 & 0.17 & 0.2 \\
\hline $\mathrm{Al}_{2} \mathrm{O}_{3}$ & 1.56 & 3.54 & 1.87 & 12.66 & 4.08 & 4.38 & 4.45 \\
\hline $\mathrm{Cr}_{2} \mathrm{O}_{3}$ & 0.41 & 0.42 & 0.41 & 0 & 0.33 & 0.35 & 0.38 \\
\hline $\mathrm{FeO}$ & 5.6 & 11.03 & 6.44 & 11.16 & 7.41 & 7.96 & 8.05 \\
\hline $\mathrm{MnO}$ & 0.11 & 0.21 & 0.13 & 0.19 & 0.14 & 0.15 & 0.14 \\
\hline $\mathrm{MgO}$ & 43.13 & 32.63 & 41.50 & 9.8 & 35.00 & 37.60 & 37.8 \\
\hline $\mathrm{CaO}$ & 0.69 & 5.05 & 1.37 & 10.53 & 3.24 & 3.49 & 3.55 \\
\hline $\mathrm{Na}_{2} \mathrm{O}$ & 0.08 & 0.47 & 0.14 & 2.37 & 0.60 & 0.64 & 0.36 \\
\hline $\mathrm{K} 2 \mathrm{O}$ & 0.03 & 0.19 & 0.05 & 0 & 0.04 & 0.05 & 0.03 \\
\hline $\mathrm{NiO}$ & 0.25 & 0.25 & 0.25 & 0 & 0.20 & 0.21 & 0.25 \\
\hline Total & 100 & 100 & 100.00 & 100 & 100.00 & 100.00 & 100.21 \\
\hline
\end{tabular}

Table 2. Source of Barberton komatiite calculated by adding 0.155 komatiite 49J (Sun and Nesbitt, 1978) and 0.845 Kaapvaal Peridotite PHN4265 (Boyd and Mertzman, 1987; Herzberg, 1993); source of iron-rich basalt calculated by adding 0.205 Iron-rich basalt ACH7 (BVSP, 1981) and 0.795 Barberton source; Primitive Mantle calculated by subtracting $14 \%$ of total Si from ACH7 source. Primitive Mantle of McDonough and Sun (1995) is presented for comparison.

Metasomatism of granular peridotite is required to increase light rare earth contents. This, together with the very high degrees of melting during their genesis, is attributed to a volatile-rich system. Granular peridotites formed relatively late, after addition of volatiles to the earth by CM meteorites (Hatton, 1997). The source of sheared peridotites developed earlier, soon after the moon-forming impact which devolatilised the earth

\section{References.}

Anderson DL (1983) Chemical composition of the mantle. Journal of Geophysical Research 88(Suppl.): B41-B52.

Boyd, F.R., Mertzman, S.A. (1987) Composition and structure of the Kaapvaal lithosphere, southern Africa. In Mysen BO (editor) Magmatic Processes: Physiochemical Principles. Geochemical Society, Special Publication 1:13-24.

Basaltic Volcanism Study Project (1981). Basaltic volcanism on the Terrestrial Planets. Pergamon, New York. 1286 pp. 
Ehrenburg, S.N. (1979) Garnetiferous ultramafic inclusions in minette from the Navajo Volcanic Field. in Boyd, F.R., Meyer, H.O.A. (editors) The Mantle Sample: Inclusions in Kimberlites and Other Volcanics. American Geophysical Union, Washington DC. Proceedings of the Second International Kimberlite Conference vol. 2, pp. 330-334.

Gurney, J.J., Harte, B. (1980) Chemical variations in upper mantle nodules from southern African kimberlites. Philosophical Transactions of the Royal Society of London A297:273-293.

Hatton, C.J. (1993) Monastery majorite garnets - deep mantle subduction and origin of asthenospheric diamonds. AARL internal report KR93/391.

Hatton CJ (1997) The superocean cycle. South African Journal of Geology 100:301310.

Herzberg, C.T. (1993) Lithosphere peridotites of the Kaapvaal craton. Earth and Planetary Science Letters 120:13-29.

McDonough, W.F., Sun, S-s (1995) The composition of the Earth. Chemical Geology 120:223-253.

Moore, R.O., Gurney, J.J., Griffin, W.L., Shimizu, N. (1991) Ultra-high pressure garnet inclusions in Monastery diamonds: trace element abundance patterns and conditions of origin. European Journal of Mineralogy 3:213-230.

Shimizu N (1975) Rare earth elements in garnets and clinopyroxenes from garnet lherzolite nodules in kimberlites. Earth and Planetary Science Letters 25:26-32.

Shimizu N, Allègre CJ (1978) Geochemistry of transition elements in garnet lherzolite nodules in kimberlites. Contributions to Mineralogy and Petrology 67:4150 .

Smith, D., Griffin, W.L., Ryan, C.G. (1993) Compositional evolution of hightemperature sheared lherzolite PHN1611. Geochimica et Cosmochimica Acta 57:605-613.

Sun, S-S., Nesbitt, R.W. (1978) Petrogenesis of Archaean ultrabasic and basic volcanics: evidence from rare earth elements. Contributions to Mineralogy and Petrology 65:301-325.

Taylor SR, McLennan SM (1985) The Continental Crust: its Composition and Evolution. Blackwell Scientific Publications, Oxford, 312 pp.

Walker, R.J., Carlson, R.W., Shirey, S.B., Boyd, F.R. (1989) Os, Sr, Nd, and Pb isotope systematics of southern African peridotite xenoliths: Implications for the chemical evolution of subcontinental mantle. Geochimica et Cosmochimica Acta 53:1583-1595. 